\title{
The Impact of the Interest Rate Liberalization on Both Banks and Small Firms: Evidence from China
}

\author{
Qishui $\mathrm{Chi}^{1} \&$ Shiwen $\mathrm{Fu}^{1}$ \\ ${ }^{1}$ Business School, Shantou University, Shantou, China \\ Correspondence: Qishui Chi, Shantou University, Shantou 515063, China.
}

Received: September 16, 2016

Accepted: October 6, 2016

Online Published: November 24, 2016

doi:10.5430/rwe.v7n2p26

URL: http://dx.doi.org/10.5430/rwe.v7n2p26

\begin{abstract}
More and more commercial banks have developed their business with small firms rapidly in China since the interest rate liberation reform in 1996. Many scholars have investigated how the rate liberalization influences the risk taking behaviors of banks. Meanwhile, some researchers have exploded from another perspective that how the reform would affect the firms especially its financing business. However, few of them have put two of the effects together under one shared model to find out how the liberalization affect both of the suppliers and buyers in this financial market. Thus, this article makes an empirical analysis on the issue above by using the data of five biggest commercial banks in China from 2004 to 2015, trying to find out the interactive effect it has on both of the market players. We put a multiplication factor into the analysis model and use GMM regression method. The results show that under the situation of interest rate liberalization, the bank loans of small firms will not be exposed under great non-performing risks. On the contrary, this will encourage more banks to develop business with small firms, which could be viewed as a win-win result.
\end{abstract}

Keywords: interest rate liberalization, small firms, financing business

\section{Introduction}

Interest rate is a tool that enables financial market to allocate its resources efficiently, including controlling the direction of capital flow and optimizing the allocation of capital. Thus, the interest rate liberalization is necessary for building up China's market economy. One of expected objects of interest rate reform is that financial institutions could get their independent pricing power in financial market. There are enough types and amount of products in the market for customers to make their best choice according to their preferences. Therefore, the beneficiaries of the reformation should be both sides of market players, commercial banks providing capital as well as firms demanding capital.

However, as the process of interest rate liberalization accelerated, many scholars put forward their questions. For example, does the reformation bring positive influence on the market players as expected? The question was arisen because of the two reasons as follows: (1) the definite result of interest rate liberalization, narrowing of interest margin, would decrease basic interest revenue commercial banks earn, which must be a strike to banks' operation; (2) independent pricing aroused the virtual competition between banks, some banks loaned their capital to "high-risk customers" to maintain their revenue, inevitably, it increased banks' non-performing loan amount and credit risk.

Before the reformation, small firms were always difficult to get loans from banks at a relatively low interest rate. Do those firms get their capital or products they need more easily with the progress of interest rate liberalization? The research results were disappointing, for the reason that the reformation did not diminish the constraints that companies had when financing from commercial banks. Other market mechanisms were not formed yet to provide the financial market with different products or services.

Thus, whether it is an opportunity or a challenge? Under the overall view of scholars, the uncertain risk that interest rate liberalization brought to banks and firms overweighed its actual benefits. However, do all those positive expected effects of the reformation only exist in theory? The reformation was divided into many steps or periods, and the policies changed in different period. Would those disappointing conclusions changed as the years went by? The answer might be yes, because at year 2015, the last step was accomplished that the central bank announced that the upper limitation of more than one-year fixed deposit interest rate, which marked the ending of China's interest rate 
liberalization. An artwork will never look shining until it is completed.

\section{Literature Review}

The reform of China's interest rate liberalization has been carried out intermittently since 1996. The process was slow so that consecutive data about the reformation had not been sufficient enough for what quantitative analysis needed until 2010. Thus, before 2010, most of literature studying on China's interest rate liberalization are qualitative analysis other than quantitative research. During that period, domestic scholars found out that interest rate liberalization might increase the risks commercial banks undertook, which could be divided into two categories: temporary and permanent risks. This conclusion was drawn after the observation carried out by the scholars on the difference of banks' risk-taking situation occurred before the reformation and after the reformation.

The milestone of the reformation was set in 2004 because in that year the upper limitation level of the loan rate was cancelled off. After 2010, the statistics that could be used for quantitative analysis were adequate not only due to the enough amount of data but also because the time period was long enough for the market to adjust to the policies so that the data could, to a large degree, reflect the real impact of those reformation policies on market players.

The relationship among interest rate liberalization, banks' behavior and financing business of small firms has attracted considerable attention and debate for decades. In recent years, many scholars studied this issue by applying the data of many countries. By investigating the interest rate in pre-crisis Korea, JOON-HO (2004) believes that Korean commercial banks had been significantly exposed to interest rate risk, and that the subsequent profitability of commercial banks was significantly associated with the degree of pre-crisis exposure. Therefore, the Korean case highlights the importance of upgrading financial supervision and risk management practices as a precondition for successful financial liberalization. After investigating the deposit and lending rate from 1980 to 2005 in Zambia, Odhiambo (2009) finds strong support for the positive impact of interest rate liberalization on financial deepening. By using the micro data from Thailand, Hübler, Menkhoff and Suwanaporn (2008) analyses changes in lending behavior of Thai commercial banks during a liberalization phase, and finds that liberalization evidence is consistent with more risk taking, such as lending to more risky projects and less protection against default. By studying the evidence from Ghana or the period 1970-2005, Osei-Assibe and Baah-Boateng (2012) investigates the relationship between the interest rate deregulation and private investment of small business. The study's finds a statistically significant and positive relationship between real deposit interest rate and financial savings as well as between bank credit and financial savings, the net effect of a real deposit rate on investment is found to be negative. In this regard, the findings do not seem to provide support for the McKinnon-Shaw financial liberalization hypothesis. Akinboade and Kinfack (2013) studies the interest rate reforms, financial deepening and economic growth in Cameroon, and finds that the impact of interest rate reforms on financial deepening is sensitive to the proxy used for financial deepening. Akinboade and Kinfack (2013) believes that financial repression helps improve broad money and hinders the development of the other indicators of financial development in Cameroon. Mukherjee and Bhattacharya (2015) examines the operation of the traditional Keynesian interest rate channel of the monetary policy transmission mechanism in five emerging economies in the Middle East and North Africa, and draws a conclusion that liberalization of the interest rate has a significantly positive impact on private sector demand in the Middle East and North Africa.

Meanwhile, many scholars investigate evidence from China. Chen and Gao (2010) takes the sample of five domestic joint-equity commercial banks, trying to analyze the interest rate exposure of those banks from the perspectives of "debt to assets ratio", "interest revenue ratio" and "capital adequacy ratio" under an empirical way, which means taking interest rate exposure as the dependent variable and those internal characteristic bank variables as independent variables to reflect the impact that interest rate liberalization has on the market. The result shows that the interest rate exposure increases as the reformation is been developed. However, two defects of that research are put forward. One is that, as for the selection of the independent variables, there are not enough information about the impact of reformation on commercial banks because banks are not individual player in this market, every decision that banks made depends on their competitor banks' performance in the market. Therefore, internal variables are not enough, external variables which reflect the interaction of banks, especially the competition factors, are equally important to be considered as independent variables. Second is that, as for dependent variables, interest rate exposure is just one part of the risks a bank would be faced with, other kind of operational risks should be taken into consideration as well. In order to solve the first defect, scholars tended to add more independent variables in their research which are factors showing the interaction between banks. Zhang and Wu (2012) focuses mostly on how the interest rate competition brought by the reformation affected the banks' risk-taking. They apply Driscoll-Kraay robust standard error to analyze the sample. As the conclusion, due to the existence of interest rate competition, the credit risk banks 
are faced with has been decreased, as for the operation risk, as a whole, is not significantly increased by the reformation. Tang and Liu (2014) is curious more about the loan competition between banks, so the index "Lerner" is used to measure the degree of intense loan competition. When interest rate liberalization brought more intense loan competition in the market, the fluctuation of banks' revenue as well as bankrupt risk of banks were lowered. Besides interest rate exposure, banks' operational risks consist of bankruptcy risk, non-performing risk, etc. Zuo and Tang (2014) adds one indicator "non-performing risk" as the dependent variable to do the research on whether deposit rate liberalization increased banks' operational risk. The result shows that although the narrowing of interest margin can decrease the variance of bank revenue, however, the intense price competition between banks will increase banks' non-performing risk. When scholars create a bigger research sample either by increasing the amounts of sample banks or by making the sample period longer, the conclusions are all surprising. Zuo and Tang (2014) does an empirical research on the risk-taking of 14 domestic commercial banks after the interest rate liberalization, which draws to a conclusion that the reformation does not increase banks' risk-taking, and also, the increasing kinds of business will decrease the variance of revenue and the possibility of bankruptcy. Li and Liu (2015) does a research on 49 domestic commercial banks from 1997 to 2013, which covers the period of the whole reformation, and concluded that the risk-taking are decreasing as the reformation is carried out. To explain that, the idea that the pace of reformation is slow enough that the banks in the market had sufficient time to adapt to each policy and performed well is put forward.

If say, the impact interest rate liberalization brought to banks could be defined as the impact on the seller side of the market, so the impact on small firms could be defined as the impact on buyer side. Many scholars try to study the effects of reformation from the perspective of buyer sides. Some literature such as Yue (2009) agree that the narrowing of interest rate gap will force banks to positively lend their money to customers in order to maintain their revenue, especially target small firms which can bring high revenue margin to them, vice versa, customers'(small firms) need will be better satisfied. See more empirical research, from Wang and Zhang (2007), it can be found that after the upper limitation of loan interest rate is cancelled off, the level of business liabilities is rising, which can help solving the difficulty of firm financing. However, Wang and Lu (2015) refutes that conclusion giving the reason that they find out in fact, the relationship between the scale of small firms financing and the change of loan interest rate is not significant. Thus, whether small firms financing could benefit from the reformation is still a mystery which worth being studied.

To summarize, those research are being improved both by choosing more suitable variables and by making the research questions more detailed. However, there are some deficiencies if we hold a critical attitude toward former literatures. This article tries to develop the existing research from 2 perspectives: (1) the impact of interest rate liberalization on commercial banks risk-taking; (2) the impact of interest rate liberalization on small firms financing.

\section{Hypothesis}

Before the empirical analysis in this article, we present three hypotheses for the study.

$\mathrm{H}_{1:}$ If banks lend loans to small firms, how largely will them transfer to non-performing assets?

Most of time, banks tend to lend their capital to big firms for two reasons. One is that their credit information is transparent and trustworthy in the market, banks could make their decision based on it at a low information-searching cost. On the other hand, as for big companies, their cash flow is usually stable which could be calculated from their stable business, which is to say, there is little possibility that big firms would break their promise. On the contrary, it seems more difficult for banks to collect small firms' credit background information, due to the existence of information asymmetry. In addition, capital that small firms need is relatively petty loan, banks must spend a lot of energy and separate their attention on getting the loan back. Thus, with insufficient supervision, small firms are more usually to transfer into subprime customers and contribute to banks' non-performing assets.

So, here we suppose that there is a positive correlation between the possibility of non-performing loans and the amount of the petty loans to small firms.

$\mathrm{H}_{2:}$ Does interest rate liberalization bring commercial banks more non-performing loans?

As the limitation of interest rate gradually being cancelled off, the gap between the loan interest rate and the deposit interest rate is narrowing and narrowing. In addition, the reformation, in fact, deprives government's right of pricing, instead, offers the market the chance to determine the price. When market determines the price, the competition between each banks will grow intense. As a possible result, many banks would like to lend their capital to small firm customers to gain a high rate of return. Based on the first hypothesis we have already made, small firms, due to its lacking credit information or bad credit record, are always harder to get trusts or credits from banks, thus, they 
usually pay banks more on the interest rate to cover the possible risks they might bring to banks. Moreover, as for small firms, cash flow is not that stable as big firms in the market, if unfortunately, their business run bad, faced with high loan rate, there is a large possibility to go bankruptcy and break the contract with banks. Thus, usually, small firms are easy to transfer to so-called "subprime customers", which bring banks more non-performing assets.

Thus, here we would like to suppose that under interest rate liberalization, banks will easily expose themselves to high non-performing risks. The answer is yes, there is a positive correlation between the non-performing risk and the degree of the reformation.

$\mathrm{H}_{3:}$ Does the reformation benefits banks and small firms in their financing business?

As the reformation developed, situations began to change as well. Fierce competition forced banks to move on to a new target market, small firms, to own market share. To realize it, banks started to design some loan products which target exclusively on small banks. Besides, each bank has gradually improved their credit information collecting system in order to get rid of information asymmetry disadvantage. Those actions to large degree decrease the risks when banks lend loans to small firms, and vice versa, encourage small firms to cooperate with banks.

Thus, we suppose that the reformation would benefit the market because the positive actions taken by banks would lower the possibility (we suppose in hypothesis 2) of the small firms' loans transferring to non-performing assets of banks, which in detail is, the risk contributor that small firms bring to banks will be lowered.

\section{Empirical Analysis}

\subsection{Descriptive Statistics of Variables}

In order to verify the three hypotheses above, let NPLR represents the risk of non-performing loans, and SFLONGR, NIM, X1, X2 represent the change rate of small firm's loans, the degree of freedom of interest rates the internal and external variables respectably, we established econometric model as follows:

$$
\Delta N P L R_{i t}=\beta_{0}+\beta_{1} S_{F L O A N G R}+\beta_{2} N_{i t} M_{i t}+\beta_{3} N I M_{i t} \times S F L O A N G R_{i t}+\beta_{4} X_{1 i t}+\beta_{5} X_{2 i t}+\mu_{i}+\varepsilon_{i t}
$$

where the letter i represents the different commercial banks. The variable X1 includes LOANGR, RLR, LDR, BANKSIZE, CCAR, which show the characteristics of a bank. X2 includes GDPGR and LM2GR.

By applying the wind database, we got panel data of 5 large listed commercial banks in China from 2004 to 2015. The banks are China Construction Bank, ICBC, Bank of Communications, Bank of China and Agricultural Bank of China.

Table 1. Descriptive statistics of variables

\begin{tabular}{ccrrrr}
\hline variable & the meaning of variable & $\begin{array}{c}\text { minimum } \\
\text { value }\end{array}$ & $\begin{array}{c}\text { maximum } \\
\text { value }\end{array}$ & mean & \multicolumn{2}{c}{$\begin{array}{c}\text { standard } \\
\text { deviation }\end{array}$} \\
\hline NPLR & non-performing loan ratio & .86 & 5.12 & 2.1334 & 1.26262 \\
SFOANGR & growth rate of small firms' loan & -.08 & 4.37 & .3968 & .64922 \\
NIM & net interest margin & 2.00 & 3.70 & 2.5532 & .29387 \\
& the interaction item of SFOANGR and & -.19 & 11.62 & 1.0562 & 1.77956 \\
SN & NIM & 5.80 & 49.72 & 15.3635 & 6.51853 \\
LOANGR & annual rate of change of loan & 1.23 & 1.97 & 1.7487 & .12319 \\
LNRLR & logarithm of real lending rate & 46.88 & 76.06 & 64.4796 & 6.82593 \\
LDR & loan to deposit ratio & 9.35 & 12.31 & 11.2352 & .70509 \\
LBANKSIZE & logarithm of total assets of bank & 4.22 & 12.20 & 9.6564 & 1.63063 \\
CCAR & core capital adequacy ratio & 6.90 & 14.20 & 9.7333 & 2.15239 \\
GDPGR & annual growth rate of GDP & -2.81 & -1.07 & -1.8801 & .42889 \\
LM2GR & logarithm of annual growth rate of M2 & & &
\end{tabular}




\subsection{GMM Estimation}

In this article we used the system GMM method to deal with the panel data of the bank risk. The reason for doing this are shown as follows:

First of all, we found endogenous problem after testing the explanatory variable, so the OLS regression method can't be used here, and the instrumental variables should be applied to solve the problem of endogenous variable.

Secondly, we checked out heteroscedasticity after having done the heteroscedasticity and autocorrelation test, that is why 2SLS estimation method can't be used in this article.

Finally, we drew a conclusion that the model was most likely to pass the test if the loan to deposit ratio was selected as a tool variable for GMM regression.

By applying STATA, the results of GMM estimation are shown in the table below.

Table 2. The results of GMM estimation

\begin{tabular}{crrrrrr}
\hline DNPLR & Coef. & Std.Err. & $\mathrm{z}$ & $\mathrm{P}>\mathrm{z}$ & \multicolumn{1}{c}{$95 \%$} & Conf.Interval \\
\hline LDR & .0131191 & .006337 & 2.07 & 0.038 & .0006988 & .0255394 \\
SFLOANGR & 1.180906 & .4755276 & 2.48 & 0.013 & .2488884 & 2.112923 \\
NIM & .5745719 & .1977998 & 2.90 & 0.004 & .1868914 & .9622523 \\
SN & -.4607732 & .1779913 & -2.59 & 0.010 & -.8096297 & -.1119168 \\
LOANGR & -.0218782 & .0047431 & -4.61 & 0.000 & -.0311746 & -.0125818 \\
LBANKSIZE & -.176116 & .0672982 & -2.62 & 0.009 & -.3080181 & -.0442139 \\
CCAR & .0382222 & .0240133 & 1.59 & 0.111 & -.008843 & .0852874 \\
LNRLR & -.5951367 & .4246423 & -1.40 & 0.161 & -1.42742 & .2371469 \\
GDPGR & -.1082152 & .0203875 & -5.31 & 0.000 & -.1481739 & -.0682565 \\
LM2GR & -.2921721 & .0760562 & -3.84 & 0.000 & -.4412395 & -.1431047 \\
CONS & .9815776 & 1.402267 & 0.70 & 0.484 & -1.766815 & 3.72997 \\
\hline ridentification test (Anderson canon. corr. LM statistic): & & 37.292 &
\end{tabular}

Underidentification test (Anderson canon. corr. LM statistic):

$$
\text { Chi-sq(1) P-val .0000 }
$$

Weak identification test (Cragg-Donald Wald F statistic):

Stock-Yogo weak ID test critical values: 10\% maximal IV size

92.662

$$
16.38
$$

$\begin{array}{ll}15 \% \text { maximal IV size } & 8.96 \\ 20 \% \text { maximal IV size } & 6.66 \\ 25 \% \text { maximal IV size } & 5.53\end{array}$

Source: Stock-Yogo (2005). Reproduced by permission.

Sargan statistic (overidentification test of all instruments): 0.000

(equation exactly identified)

Instrumented: $\quad$ ldr

Included instruments: sfloangr nim sn loangr lbanksize ccar lnrlr gdpgr lm2gr

Excluded instruments: L.ldr

\subsection{Empirical Result Analysis}

From the regression result table, we can see that the coefficient of independent variable "SFLOANGR" is positive, which proves that the incremental quantity of non-performing risks are positively correlated with the incremental quantity of loans banks lend to small firms. When banks develop their new target market, their non-performing assets are also increasing. In addition, actual data from CMBC also shows in 2014, when the bank was developing their small firms business, the non-performing rate contributed by small firms was $2.83 \%$, increasing $0.9 \%$ compared to last year. Therefore, hypothesis 1 has been proved to be right. 
The empirical model has passed "over identification test" and "sargan test", which means the instrument variable fits this case, so we could say that the model was set reasonably. Moreover, the model fits the data well because the R square of the model equals to 0.7662 . In all, the model is trustworthy and suitable.

As for variable "NIM", its coefficient is significantly positive because its P value is only 0.004 . That is to say, it can't be refused that there is a negative relationship between the interest rate gap and the non-performing risks banks are exposed to. As the reformation develops, the gap (NIM) begins to narrow, in the meanwhile, the incremental quantity of risks is narrowing as well, which means the variance is decreasing, the risk tends to become stable than before. Thus, we could say that the non-performing risks are not aggravating, but on the contrary, tend to decrease.

This article figures out some of the possible reasons to help empirical results make more sense. The samples are taken from the five big domestic firms which have strong monopoly power Because of the brand effect of the five banks, when developing a new market, superior high potential small firms will tend to choose these big commercial banks instead of other small banks. Superior firms will run a stable business which enables them to pay their loans on time. Moreover, the good brand effect will also help banks to maintain their customers when the competition becomes fierce after the reformation, which is usually described as customer loyalty. Those firms do not need to lower a lot their interest rate to maintain their customers. As a result, the influence to banks' revenue is not as much as to other small banks, which allows them to offset their dud-loans. Large-scaled banks have their own research team to do study on how to improve their asset management and reduce the risk exposure. With a sophisticated risk-controlling and risk-preventing mechanism, the big banks still have methods to solve the problems although the customers might be subprime. With their huge amount of equity capital, non-performing assets will be handled in a short time. Thus, there seems to be little strike to their business after the reformation.

According to the regression results (table 2), we get a surprising conclusion from the cross-term in the model. The cross-term is defined as how variable "MAR" changes the relationship between independent variable "SFLOANGR" and dependent variable "non-performing risk". The coefficient of the cross-term is negative, which means that though loans lent to small firms will increase the non-performing risks of banks, however, due to the force of interest rate liberalization, the degree will be decreasing, small firms loan will not contribute that much to banks' dud-loan, the possibility of small firms loan transferring into dud-loan will reduce. This result makes hypothesis 3 stand. One thing worth to be mentioned is that although the conclusion shows the benefit that the interest rate liberalization has brought to the market, the effect of the benefit will reduce as the reformation develops, which means as the interest rate gap narrows. However, this does not mean that this conclusion expresses a pessimistic toward the reformation, because every policy follows a golden economic rule, that is, diminishing marginal utility. The benefit we get from the result could be viewed as the utility or the output of the policy, however, this utility will diminish.

To simply illustrate the relationship between those controlled variables and dependent variable:

1) The change of non-performing risk is positively correlated to a bank's LDR. When loans graw faster than deposits, an increase of LDR, there is a bigger possibility that banks will make a wrong decision that they lend capital to a subprime customer, which push their non-performing risk higher.

2) There is a negative relationship between the change of non-performing risk and the growth of loans. These five domestic banks are under the strict supervision of the authority. Large change in non-performing assets is almost impossible to happen.

3) The change of non-performing risk is negatively correlated with the scale of its assets. The larger the scale of assets is, the more assets management experience it owns, the stronger capability that it owns to handle the non-performing assets.

4) There is a negative relationship between the change of non-performing risk and the growth of GDP. When a country's GDP value grows fast, the macroeconomic environment is stable, the return of production and investment tends to be higher, which lowers the possibility of firms breaking their promise. From 2014 to 2016 , China's GDP growth is relatively lowered than before, it is easily found that the non-performing risk banks are faced with go higher.

5) There is a negative relationship between the change of non-performing risk and the growth of M2. The growth of M2 will result in prosperity of market, which works as the same mechanism as the growth of GDP.

6) Variables "CCAR" and "LNRLR" are insignificant variables in this model. Although they are not statistically significant, they might have indirect correlation with dependent variables. 


\section{Conclusion}

This article tries to examine whether China's interest rate liberalization bring benefits to the market by constructing a cross-term of small firms loan growth and the degree of the reformation in the empirical model. To make the research more meaningful, the sample was chosen to be five domestic banks which develops their new target market, small firms market. Therefore, the regression result could also be used to examine whether those five banks made a right decision toward the interest rate liberalization. We collect the data from 2004 to 2015 and use the empirical method GMM to do the regression test. The empirical results could be interpreted to three key conclusions of this article. Firstly, China's interest rate liberalization offers the market the right to determine the price, but in the meanwhile, it does not increase the non-performing risk-taking of banks, on the contrary, the risk tends to reduce. Secondly, as an opportunity, the reformation encourages banks in the market to develop more business toward small firms, which solves the problems small firms are faced with when financing. However, the increase of small firm business will probably increase banks' risk exposure. Finally, it could be regarded as one of the biggest advantage of the reformation that small firms loan will not contribute that much to banks' dud-loan, the possibility of small firms loan transferring into dud-loan will reduce for the reason that the narrowing of interest rate gap brought by interest rate liberalization will force banks to take every action to reduce the risk new target market bring to themselves. Therefore, we could get to the final conclusion that China's interest rate liberalization brings the market a win-win situation.

The results of this study verify the banks' countermeasures of developing the financing business with small firms. Under the background of interest rate liberalization, active lending to small firms can be regarded as an effective way to increase profit, because it will bring considerable interest for banks without additional risks. However, this kind of mutual promotion and cooperation is likely to be gradually weakened with the further deepening of reform in the future. What should market players do to maintain this win-win situation? For commercial banks, the quality of small firms such as high-tech small enterprises can be selected as their potential customer base. Moreover, it is very important to realize the diversification of income sources to get rid of the shackles of traditional income spreads. The government can make appropriate standards to decide which small firms should be put into an asset pool, and it should open this market when the small firms in the asset pool are quality enough. In this way, Chinese commercial banks can transfer their screening cost to the government. This will significantly reduce the cost of the bank and make quality enterprises to get better financial services.

\section{Acknowledgements}

We acknowledge the research support of Guangdong Provincial Department of Science \& Technology via the Grant of Soft Science Research Project 2016A070705059. We also acknowledge the research support of Shantou University via its 2016 Annual National Fund Cultivation Project.

\section{References}

Akinboade, O.A., \& Kinfack, E.C. (2013). Interest rate reforms, financial deepening and economic growth in Cameroon: an empirical investigation. Applied Economics, 25, 3574-3586. http://dx.doi.org/10.1080/00036846.2011.566200

Chen, K., \& Gao, H. (2010). An analysis of risk of interest rate liberalization in commercial banks. Economic Theory and Business Management, 3, 57-61.

Hübler, O., Menkhof, L., \& Suwanaporn, C. (2008). Financial Liberalization in Emerging Markets: How Does Bank Lending Change?. World Economy, 3, 393-415. http://dx.doi.org/10.1111/j.1467-9701.2007.01067.x

Joon-Ho, H. (2004). Interest rate and exchange rate exposures of banking institutions in pre-crisis Korea. Applied Economics, 13, 1409-1419.

Li, C., \& Liu, S. F. (2015). Does interest rate liberalization make the commercial banks take more risks: the empirical evidence from Chinese Banking. Economic Management Journal, 12, 91-102.

Mukherjee, S., \& Bhattacharya, R. (2015). Do the Keynesian monetary transmission mechanisms work in the MENA region?. Empirical Economics, 3, 969-982. http://dx.doi.org/10.1007/s00181-014-0824-8

Odhiambo, M. (2009). Interest Rate Liberalization and Economic Growth in Zambia: A Dynamic Linkage. African Development Review, 3, 541-557. http://dx.doi.org/10.1111/j.1467-8268.2009.00222.x

Osei-Assibe, E., \& Baah-Boateng, W. (2012). Interest Rate Deregulation and Private Investment: Revisiting the McKinnon-Shaw Hypothesis in Ghana. IUP Journal of Applied Economics, 2, 12-30. 
Tang, X.G., \& Liu, Y.Z. (2014). Effect of banking loan: competition on financial stability. Journal of Finance and Economics, 1, 100-108.

Wang, D.J., \& Zhang, X.J. (2007). Research on interest rate market-oriented reform, corporate finance and credit behavior of financial institutions. The Journal of World Economy, 2, 50-59.

Wang, D.P., \& Yang, J. (2014). Interest rate liberalization, deposit insurance and bank risk. Nankai Journal (Philosophy, Literature and Social Science Edition), 6, 117-128.

Wang, X.X., \& Lu, D.Y. (2015). Market-oriented reform of interest rate and financing of small and medium-sized enterprises. Journal of Xi'an University of Finance and Economics, 2, 15-18.

Yu, Y. (2009). Study on the interest rate liberalization and small firms' financing business. Shandong Social Sciences, $11,122-124$.

Zhang, Z.Y., \& Wu, J. (2012). The relationship between price competition and risk behavior of commercial banks. Journal of Financial Research, 7, 1-14.

Zuo, Z., \& Tang, X.G. (2014). Will the interest rate liberalization of deposit increase the risk. Journal of Finance and Economics, 2, 20-29. 